\title{
Brucella inopinata sp. nov., isolated from a breast implant infection
}

Holger C. Scholz, ${ }^{1}$ Karsten Nöckler, ${ }^{2}$ Cornelia Göllner, ${ }^{2}$ Peter Bahn, ${ }^{2}$
Gilles Vergnaud, ${ }^{3,4}$ Herbert Tomaso, ${ }^{1}$ Sascha Al Dahouk,
Peter Kämpfer, ${ }^{6}$ Axel Cloeckaert, ${ }^{7}$ Marianne Maquart, ${ }^{7}$
Michel S. Zygmunt, ${ }^{7}$ Adrian M. Whatmore, ${ }^{8}$ Martin Pfeffer, ${ }^{1}$
Birgit Huber, ${ }^{9}$ Hans-Jürgen Busse ${ }^{9}$ and Barun Kumar De ${ }^{10}$

${ }^{1}$ Bundeswehr Institute of Microbiology, Neuherbergstrasse 11, D-80937 Munich, Germany

${ }^{2}$ Federal Institute for Risk Assessment, Diedersdorfer Weg 1, D-12277 Berlin, Germany

${ }^{3}$ DGA/D4S - Mission pour la Recherche et I'Innovation Scientifique, 7, rue des Mathurins, 92220 Bagneux, France

^Université Paris-Sud 11, CNRS, UMR8621, Institut de Génétique et Microbiologie, 91405 Orsay, France

${ }^{5}$ RWTH Aachen University, Department of Internal Medicine III, Pauwelsstraße 30, D-52074 Aachen, Germany

${ }^{6}$ Institute for Applied Microbiology, Justus-Liebig-Universitat Giessen, IFZ, Heinrich-Buff-Ring 26-32, D-35392 Giessen, Germany

${ }^{7}$ INRA, UR1282, Infectiologie Animale et Santé Publique, IASP, F-37380 Nouzilly, France

${ }^{8}$ Veterinary Laboratories Agency, Woodham Lane, Addlestone KT15 3NB, UK

${ }^{9}$ Institut für Bakteriologie, Mykologie und Hygiene, Veterinärmedizinische Universität, A-1210 Wien, Austria

${ }^{10}$ Centers for Disease Control and Prevention, 1600 Clifton Rd, Atlanta, GA 30333, USA

A Gram-negative, non-motile, non-spore-forming coccoid bacterium (strain $\mathrm{BO} 1^{\top}$ ) was isolated recently from a breast implant infection of a 71-year-old female patient with clinical signs of brucellosis. Affiliation of strain $\mathrm{BO}^{\top}{ }^{\top}$ to the genus Brucella was confirmed by means of polyamine pattern, polar lipid profile, fatty acid profile, quinone system, DNA-DNA hybridization studies and by insertion sequence 711 (IS711)-specific PCR. Strain BO1 ${ }^{\top}$ harboured four to five copies of the Brucella-specific insertion element IS711, displaying a unique banding pattern, and exhibited a unique 16S rRNA gene sequence and also grouped separately in multilocus sequence typing analysis. Strain $\mathrm{BO}^{\top}{ }^{\top}$ reacted with Brucella $\mathrm{M}$-monospecific antiserum. Incomplete lysis was detected with bacteriophages Tb (Tbilisi), F1 and F25. Biochemical profiling revealed a high degree of enzymic activity and metabolic capabilities. In multilocus VNTR (variable-number tandem-repeat) analysis, strain $\mathrm{BO} 1^{\top}$ showed a very distinctive profile and clustered with the other 'exotic' Brucella strains, including strains isolated from marine mammals, and Brucella microti, Brucella suis biovar 5 and Brucella neotomae. Comparative omp2a and omp2b gene sequence analysis revealed the most divergent omp2 sequences identified to date for a Brucella strain. The recA gene sequence of strain $B O 1^{\top}$ differed in seven nucleotides from the Brucella rec $A$ consensus sequence. Using the Brucella species-specific multiplex PCR assay, strain $B O 1^{\top}$ displayed a unique banding pattern not observed in other Brucella species. From the phenotypic and molecular analysis it became evident that strain $\mathrm{BO} 1^{\top}$ was clearly different from all other Brucella species, and therefore represents a novel species within the genus Brucella. Because of its unexpected isolation, the name Brucella inopinata with the type strain $\mathrm{BO} 1^{\top}(=\mathrm{BCCN}$ $09-01^{\top}=$ CPAM $6436^{\top}$ ) is proposed. 
The genus Brucella was constituted in 1920 by Meyer \& Shaw (1920) with Brucella melitensis, the causative agent of Malta fever, as the type species and Brucella abortus causing abortion in cattle as the second species. Within 48 years four additional Brucella species, namely Brucella suis (Huddleson, 1929), Brucella ovis (Buddle, 1956), Brucella neotomae (Stoenner \& Lackman, 1957) and Brucella canis (Carmichael \& Bruner, 1968) were described. It took nearly another 40 years before two additional species, Brucella pinnipedialis and Brucella ceti, originating from marine mammals were published (Foster et al., 2007). The most recently published description of a Brucella species is that for Brucella microti, isolated initially from common voles in the Czech Republic (Hubalek et al., 2007; Scholz et al., 2008a) and recently also from red foxes in Lower Austria (Vulpes vulpes) and directly from soil (Scholz et al., 2009, 2008c).

Before the development of molecular techniques, differentiation of the various Brucella species and their biovars was solely based on phenotypic traits, i.e. $\mathrm{CO}_{2}$ requirement, $\mathrm{H}_{2} \mathrm{~S}$ production, dye sensitivity, metabolic profiles, lysis by Brucella-specific bacteriophages and agglutination with monospecific antisera. Another important criterion for the differentiation of the various Brucella species was the natural host preference, which is why species names were given in accordance with their preferred host. Today it is known that all Brucella species are highly related at the genetic level, exhibiting identical 16S rRNA (Gee et al., 2004) and recA gene sequences (Scholz et al., 2008b) as well as highly similar genomes in terms of sequence identity and gene synteny (Del Vecchio et al., 2002; Paulsen et al., 2002; Halling et al., 2005). In the majority of housekeeping genes only single nucleotide polymorphisms are present among the various Brucella species (Whatmore et al., 2007). Indeed, applying the gold standard for species delineation, DNA-DNA hybridization (Wayne et al., 1987), all recognized Brucella species belong to a single species, as the DNA-DNA relatedness among all species is above $70 \%$ (Verger et al., 1985). Consequently, Verger et al. (1985) suggested Brucella as a monospecific genus with $B$. melitensis as the sole true species and the other species to be recognized as biovars. This perception was later confirmed by using data from comparative whole genome

Abbreviations: MLST, multilocus sequence typing; MLVA, multilocus VNTR (variable-number tandem-repeat) analysis; RTD, routine test dilution.

The GenBank/EMBL/DDBJ accession numbers for the omp2a, omp2b, omp25, omp31 and recA gene sequences of strain $B O 1^{\top}$ are FM177715, FM177716, FM177717, FM177718 and FM177719, respectively.

Figures showing lysis of strain $\mathrm{BO} 1^{\top}$ on Brucella agar by bacteriophage $\mathrm{Tb}$ (Tbilisi), a two-dimensional thin-layer chromatogram of total polar lipids of strain $\mathrm{BO} 1^{\top}$, IS711 element fingerprinting by using Southern blotting and a condensed dendrogram of clustered MLVA-16 genotypes obtained with more than 470 Brucella isolates corresponding to 324 different genotypes are available as supplementary material with the online version of this paper. sequencing analysis of $B$. melitensis (Del Vecchio et al., 2002), B. suis (Paulsen et al., 2002), and more recently of Brucella abortus strain 9-941 (Halling et al., 2005) and B. abortus vaccine strain S19 (Crasta et al., 2008).

However, in 2003, the Subcommittee on the Taxonomy of Brucella agreed unanimously on a return to pre-1986 Brucella taxonomy and reapproval of the six Brucella nomenspecies and their biovars (Meeting in Pamplona, Spain in 2003), published in 2006 by Osterman \& Moriyón (2006).

Following the currently used Brucella taxonomy we describe a novel Brucella species, Brucella inopinata sp. nov., with the type strain $\mathrm{BO}^{\mathrm{T}}$, isolated from breast implant wound fluid and blood of a 71-year-old female patient with clinical symptoms consistent with brucellosis (De et al., 2008).

B. inopinata sp. nov. is the first Brucella species that exhibits a unique 16S rRNA gene sequence and lower sequence similarities in various housekeeping genes and genes encoding outer-membrane proteins when compared with all other recognized Brucella species and hence represents the most unique species within this genus.

\section{Phenotypic analysis of strain $\mathrm{BO1}^{\mathrm{T}}$}

Phenotypic analysis of strain $\mathrm{BO}^{\mathrm{T}}$, i.e. growth behaviour on different media at various temperatures, $\mathrm{H}_{2} \mathrm{~S}$ production, $\mathrm{CO}_{2}$ requirement, agglutination with monospecific Aand $\mathrm{M}$-antisera, cellular fatty acid analysis, lysis with bacteriophage $\mathrm{Tb}$ and growth in the presence of dyes (thionin and basic fuchsin), have been described previously (De et al., 2008) and are given in the species description. The antimicrobial susceptibility pattern of strain $\mathrm{BO}^{\mathrm{T}}$ was determined using the CLSI interpretive criteria for Brucella spp. (De et al., 2008). Results are given in the species description. Additional phenotypic characterization of strain $\mathrm{BO}^{\mathrm{T}}$ carried out in this study comprised other growth characteristics, standard biochemical characterization by using API 20E, API 20NE and API ZYM (bioMérieux), extended biochemical profiling using the MICRONAUT (MERLIN Diagnostika GmbH) system, electron microscopy, and lysis with additional Brucella-specific bacteriophages, F1 and F25, as described for B. microti (Scholz et al., 2008a).

The growth characteristics of strain $\mathrm{BO} 1^{\mathrm{T}}$ resembled those of $B$. microti, characterized by very fast growth at $37{ }^{\circ} \mathrm{C}$ on various standard media, such as sheep blood agar and standard nutrient agar (both from Oxoid). On Brucella agar (Merck), growth became visible within $6 \mathrm{~h}$ of incubation at $37{ }^{\circ} \mathrm{C}$ with or without supplementary $\mathrm{CO}_{2}$ (data not shown). Single colonies of 1-2 mm were formed within 12-24 h. As determined by using transmission electron microscopy (negative staining with $1 \%$ uranyl acetate) with a JEM-1010 electron microscope at a magnification of 40000 , cells were non-flagellated and arranged individually or in irregular clusters, exhibiting a 
mean diameter of $0.5 \mu \mathrm{m}$ and a length of $1 \mu \mathrm{m}$ (Fig. 1a and b). Strain $\mathrm{BO}^{\mathrm{T}}$ agglutinated weakly with monospecific anti-M serum up to a dilution of $1: 40$ but not with anti-A serum. Incomplete lysis was observed with bacteriophages $\mathrm{Tb}, \mathrm{F} 1$ and F25 at $10^{4} \times$ routine test dilution $\left(10^{4} \times \mathrm{RTD}\right)$ but not at any other dilutions (Supplementary Fig. S1, in IJSEM Online). This finding is in contradiction to previous results (De et al., 2008), in which no lysis could be detected with phage $\mathrm{Tb}$. This can be explained by the rapid growth of strain $\mathrm{BO}^{\mathrm{T}}$. In order to detect lysis, the standard protocol had to be modified in terms of bacteria quantities and incubation periods. Briefly, Brucella agar plates were flooded with $5 \mathrm{ml}$ Brucella bouillon including $5 \mu \mathrm{l}$ of a $10^{11}$ cell suspension of $\mathrm{BO}^{\mathrm{T}} \mathrm{ml}^{-1}$. Medium in excess was removed immediately and the plates were dried at $37^{\circ} \mathrm{C}$ for $2 \mathrm{~h}$ before the various phage dilutions were applied. The incubation time of the phage dilutions was $10 \mathrm{~s}$. Plates were incubated at $37^{\circ} \mathrm{C}$ and inspected for phage lysis after $12 \mathrm{~h}$.

As described previously for B. microti (Scholz et al., 2008a), strain $\mathrm{BO}^{\mathrm{T}}$ exhibited outstanding metabolic capabilities in comparison with recognized Brucella species, sharing a series of reactions with Ochrobactrum anthropi LMG $3331^{\mathrm{T}}$ and Ochrobactrum intermedium LMG $3301^{\mathrm{T}}$. The results of the differential biochemical reactions of strain $\mathrm{BO}^{\mathrm{T}}$ in

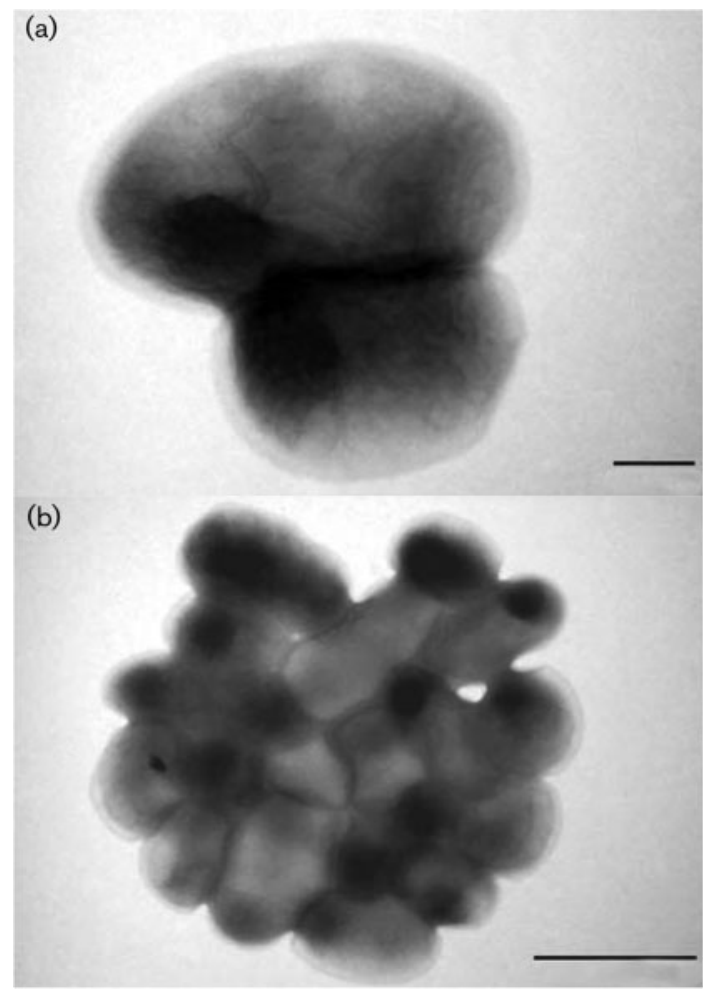

Fig. 1. Transmission electron micrographs (magnification of 40000 ) showing two inactivated non-flagellated $B$. inopinata $B O 1^{\top}$ cells (a) and a cluster of $B$. inopinata $B O 1^{\top}$ cells (b). Bars, $0.2 \mu \mathrm{m}(\mathrm{a})$ and $1 \mu \mathrm{m}(\mathrm{b})$. comparison with other Brucella species and their biovars as well as with Ochrobactrum species are summarized in Table 1. Hence, B. inopinata sp. nov. is the second fast-growing Brucella species with a highly active metabolism.

Using the API 20E and API 20NE test systems, strain $\mathrm{BO}^{\mathrm{T}}$ was misidentified as Ochrobactrum anthropi with identification scores of 98 and $99 \%$, respectively. Detailed results of API 20E, API 20NE, and API ZYM test systems are given in the species description.

Quinones and polar lipids were extracted and analysed as described by Tindall (1990a, b) and Altenburger et al. (1996). The quinone system consisted of the major compound ubiquinone Q-10 (99\%) and ubiquinone Q-11 (1\%). The polar lipid profile consisted of five major compounds: phosphatidylethanolamine, phosphatidylglycerol, diphosphatidylglycerol, phosphatidylcholine and one unknown aminolipid (Supplementary Fig. S2, in IJSEM Online). The unknown aminolipid exhibited the same chromatographic behaviour as the unknown aminolipid AL1, which was also reported to be present in the type strains of B. microti, B. melitensis and B. abortus (Scholz et al., 2008a). In addition, moderate amounts of phosphatidylmonomethylethanolamine and minor to trace amounts of an unknown aminophospholipid and an unknown phospholipid corresponding to APL2 and PL, respectively, which were detected in B. microti, as well as four unknown polar lipids were detected. One of these unknown polar lipids showed the same chromatographic behaviour as the lipid L4 present in B. microti but not in other Brucella species (Scholz et al., 2008a). Unknown aminolipid AL2 found in B. microti (Scholz et al., 2008a) as a major compound was not detectable. Hence, the polar lipid profile clearly distinguished strain $\mathrm{BO}^{\mathrm{T}}$ from $B$. microti as well as from $B$. melitensis and $B$. abortus based on the presence/absence of unknown aminolipid AL2 and unknown polar lipid L4. The polyamine pattern contained the major compounds spermidine $(45 \%)$ and putrescine (43\%) and small amounts of 1,3-diaminopropane (7\%), sym-homospermidine $(1 \%)$ and spermine $(1 \%)$. This polyamine pattern is in good agreement with those of other Brucella species (Scholz et al., 2008a).

The whole-cell cellular fatty acid profile of strain $\mathrm{BO}^{\mathrm{T}}$ was similar to those of B. abortus, B. melitensis, B. neotomae, $B$. ovis and $B$. suis, characterized by the presence of major amounts (5-46\%) of $\mathrm{C}_{19: 0}$ cyclo 11-12, $\mathrm{C}_{18: 1} \omega 7 \mathrm{c}, \mathrm{C}_{18: 0}$ and $\mathrm{C}_{16: 0}$ and smaller amounts $(1-4 \%)$ of $\mathrm{Br}-\mathrm{C}_{19: 1}$. The antimicrobial susceptibility pattern of strain $\mathrm{BO}^{\mathrm{T}}$ was comparable with profiles of other Brucella species described by Jevitt et al. (2005), with the exception of resistance to various cephalosporins (cefoxitin, cephotiam and cefuroxim). Details are given in the species description.

\section{Molecular analyses of strain $\mathrm{BO}^{\mathbf{T}}$}

Previous molecular analyses of strain $\mathrm{BO}^{\mathrm{T}}$ comprised $16 \mathrm{~S}$ rRNA gene sequencing, DNA-DNA hybridization experi- 
Table 1. Differential physiological reactions of $B$. inopinata sp. nov. $B O 1^{\top}$ in comparison with other Brucella and Ochrobactrum species

Taxa: 1, B. microti CCM 4915 ${ }^{\mathrm{T}}$; 2, B. inopinata sp. nov. BO1 ${ }^{\mathrm{T}}$; 3, B. abortus strains: $544^{\mathrm{T}}\left(=\mathrm{NCTC} 10093^{\mathrm{T}}\right)($ bv. 1$), 86 / 8 / 59$ (=NCTC 10501) (bv. 2), Tulya (=NCTC 10502) (bv. 3), 292 (=NCTC 10503) (bv. 4), B3196 (=NCTC 10504) (bv. 5), 870 (=NCTC 10505) (bv. 6), 63175 (=NCTC 10506) (bv. 7), C68 (=NCTC 10507) (bv. 9); 4, B. melitensis strains: $16 \mathrm{M}^{\mathrm{T}}$ (=NCTC 10094 ${ }^{\mathrm{T}}$ ) (bv. 1), 63/9 (=NCTC 10508) (bv. 2), Ether (=NCTC 10509) (bv. 3); 5, B . suis strains: $1330^{\mathrm{T}}$ (=NCTC $10316^{\mathrm{T}}$ ) (bv. 1), Thomsen (=NCTC 10510) (bv. 2), 686 (=NCTC 10511) (bv. 3), reference 40 (bv. 4), reference 513 (bv. 5); 6, B. ovis $63 / 290^{\mathrm{T}}\left(=\mathrm{NCTC} 10512^{\mathrm{T}}\right) ; 7$, B. canis RM6/66 ${ }^{\mathrm{T}}\left(=\mathrm{NCTC} 10854^{\mathrm{T}}\right) ; 8$, B. neotomae $5 \mathrm{~K} 33^{\mathrm{T}}\left(=\mathrm{NCTC} 10084^{\mathrm{T}}\right) ; 9$, B. pinnipedialis NCTC $12890^{\mathrm{T}}$; 10, B. ceti NCTC $12891^{\mathrm{T}}$; 11, O. anthropi LMG $3331^{\mathrm{T}}$; 12, O. intermedium LMG $3301^{\mathrm{T}}$. oNP, o-Nitrophenyl; pNP, p-nitrophenyl; $\mathrm{QO}_{2} \mathrm{~N}$, mean of 10 repetitions per reaction. + , Positive $\left(\mathrm{QO}_{2} \mathrm{~N}\right.$ values $\left.>70\right)$; - , negative $\left(\mathrm{QO}_{2} \mathrm{~N}\right.$ values $\left.<50\right)$; v, variable $\left(\mathrm{QO}{ }_{2} \mathrm{~N}\right.$ values $>50$ and $<70$ ).

\begin{tabular}{|c|c|c|c|c|c|c|c|c|c|c|c|c|c|}
\hline Compound & 1 & 2 & 3 & 4 & 5 & 6 & 7 & 8 & 9 & 10 & 11 & 12 & Substrate class \\
\hline L-Glutamine & + & + & - & - & - & - & - & - & - & - & + & + & Amino acid \\
\hline L-Histidine hydrochloride & + & + & - & - & - & - & - & - & - & - & + & + & Amino acid \\
\hline L-Citrulline & + & + & - & - & - & - & - & - & - & - & + & + & Amino acid \\
\hline DAPI & + & + & - & - & - & - & - & - & - & - & + & + & Amino acid \\
\hline Fumaric acid & + & + & - & - & - & - & - & - & - & - & + & + & Org. acid \\
\hline Succinic acid & + & + & - & - & - & - & - & - & - & - & + & + & Org. acid \\
\hline$\alpha$-Ketoglutaric acid & + & + & - & - & - & - & - & - & - & - & + & + & Org. acid \\
\hline Itaconic acid & + & + & - & - & - & - & - & - & - & - & - & - & Org. acid \\
\hline Mesaconic acid & + & + & - & - & - & - & - & - & - & - & - & - & Org. acid \\
\hline Glutaric acid & + & + & - & - & - & - & - & - & - & - & + & + & Org. acid \\
\hline oNP $N$-Acetyl- $\alpha$-D-galactosaminide ( $\mathrm{pH} 7.5)$ & + & + & - & - & - & - & - & - & - & - & + & + & Esterase \\
\hline oNP $N$-Acetyl- $\beta$-D-galactosaminide $(\mathrm{pH} 7.5)$ & + & + & - & - & - & - & - & - & - & - & + & + & Esterase \\
\hline pNP $N$-Acetyl- $\beta$-D-glucosaminide (pH 7.5) & + & + & - & - & - & - & - & - & - & - & + & + & Esterase \\
\hline pNP $N$-Acetyl-1-thio- $\beta$-D-glucosaminide ( $\mathrm{pH} 7.5$ ) & $\mathrm{V}$ & + & - & - & - & - & - & - & - & - & + & + & Esterase \\
\hline $\begin{array}{l}\text { 4-Nitrophenyl- } \alpha \text {-D-maltoheptaoside-4,6, } O \text {-ethylidene } \\
(\mathrm{pH} 7.5)\end{array}$ & + & + & - & - & - & - & - & - & - & - & + & + & Esterase \\
\hline pNP $N$-Acetyl- $\beta$-D-glucosamide ( $\mathrm{pH} 5.5$ ) & + & + & - & - & - & - & - & - & - & - & + & - & Esterase \\
\hline pNP $N$ - $\alpha$-L-Arabinopyranoside (pH 7.5) & + & + & - & - & - & - & - & - & - & - & + & + & Glucosidase \\
\hline oNP $N$ - $\beta$-D-Xylopyranoside (pH 7.5) & + & + & - & - & - & - & - & - & - & - & + & + & Glucosidase \\
\hline pNP $N$-1-thio- $\beta$-D-Galactopyranoside (pH 7.5) & + & + & - & - & - & - & - & - & - & - & + & + & Glucosidase \\
\hline $\begin{array}{l}\text { 2-Methoxy-4-(2-nitrovinyl)-phenyl } \beta \text { - } D \text { - } \\
\text { galactopyranoside }\end{array}$ & + & + & - & - & - & - & - & - & - & - & + & + & Glucosidase \\
\hline Voges-Proskauer reaction & + & + & - & - & - & - & - & - & - & - & + & + & $\begin{array}{l}\text { Classical } \\
\text { reaction }\end{array}$ \\
\hline oNP $\beta$-D-Galactopyranoside-6-phosphate & + & + & - & - & - & - & - & - & - & - & + & + & Phosphatase \\
\hline $\begin{array}{l}\text { pNP Phosphate-di(2-amino-2-ethyl-1,3-propanediol) } \\
\text { (pH 5.5) }\end{array}$ & + & + & - & - & - & - & - & - & - & - & + & + & Phosphatase \\
\hline
\end{tabular}

ments, multilocus sequence typing (MLST) analysis and IS711-specific PCR (De et al., 2008). DNA-DNA reassociation of $>70 \%$ between strain $\mathrm{BO}^{\mathrm{T}}$ and the type strains of B. melitensis $(80 \%)$ and B. suis $(78 \%)$ as well as the presence of the Brucella-specific IS711 element clearly demonstrated that strain $\mathrm{BO}^{\mathrm{T}}$ is a member of the genus Brucella. However, the data from 16S rRNA gene sequencing and MLST analysis also revealed that strain $\mathrm{BO} 1^{\mathrm{T}}$ was 
markedly different from all recognized Brucella species and their biovars. For example, strain $\mathrm{BO} 1^{\mathrm{T}}$ is characterized by a unique $16 \mathrm{~S}$ rRNA gene sequence differing in five nucleotides when compared with the 16S rRNA gene consensus sequence of Brucella species and also exhibits a significantly lower level of sequence similarity in various housekeeping genes (De et al., 2008).

In this study, we have additionally sequenced the $\operatorname{rec} A$, omp2a/b, omp25 and omp31 genes as described for B. microti (Scholz et al., 2008a). As shown previously, all recognized Brucella species, including B. microti, are identical in their recA gene sequences (Scholz et al., 2008b). However, the partial $r e c A$ gene sequence of strain $\mathrm{BO}^{\mathrm{T}}$ (GenBank no. FM177719) differed in seven of 631 nucleotides (98.9\% identity). These findings again emphasized the unique position of strain $\mathrm{BO}^{\mathrm{T}}$ within Brucella. As in MLST analysis, the various omp gene sequences of strain $\mathrm{BO}^{\mathrm{T}}$ also exhibited lower sequence similarities. The omp31 gene (723 bp) was only $96 \%$ identical to the respective sequences of other Brucella species. The omp25 gene (642 bp) sequence of strain $\mathrm{BO} 1^{\mathrm{T}}$ was most closely related to omp 25 of $\mathrm{B}$. suis ATCC 23445 (GenBank no. CP000911) with a similarity of $99 \%$. In the phylogenetic analysis using the neighbourjoining method, the omp2a and $o m p 2 b$ gene sequences of $\mathrm{BO}^{\mathrm{T}}$ were most closely related to omp $2 a / b$ of Brucella strain 83-210 (83/13), an isolate with uncertain affiliation (Fig. 2), and differed considerably (97-98\% sequence similarity) from omp gene sequences of other Brucella species.

In addition to sequencing of the above-mentioned genes, strain $\mathrm{BO}^{\mathrm{T}}$ was characterized by using AMOS PCR (Bricker \& Halling, 1994) and species-specific multiplex PCR (Garcia-Yoldi et al., 2006). In multiplex PCR analysis a unique pattern of six PCR fragments (150 bp, $272 \mathrm{bp}$, $450 \mathrm{bp}, 587 \mathrm{bp}, 794 \mathrm{bp}$ and $1682 \mathrm{bp}$ ), not observed in

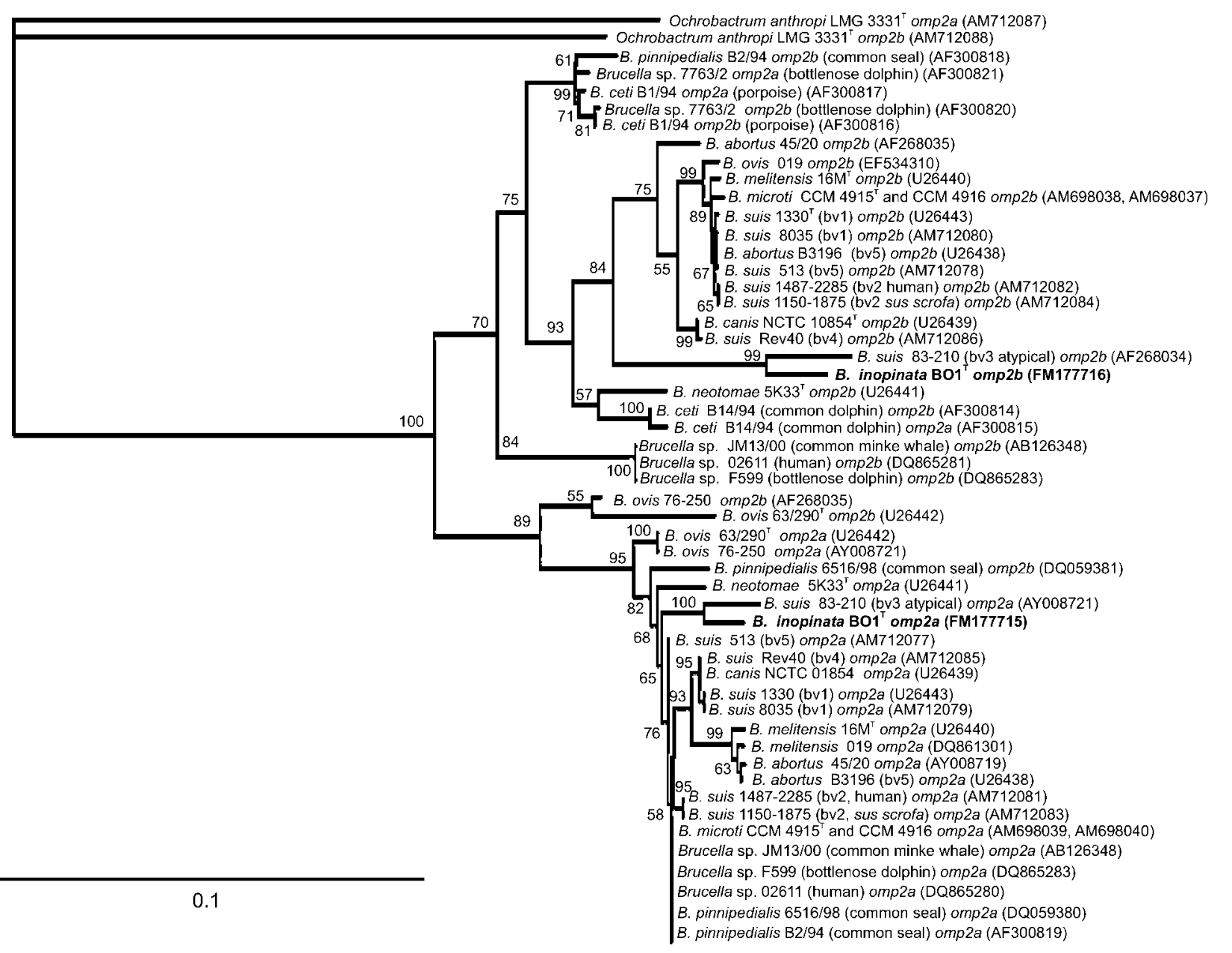

Fig. 2. Phylogenetic tree reconstructed with omp2a (1104 nt) and omp2b (1089 nt) sequences using CLUSTREE neighbourjoining analysis (Thompson et al., 1994) and Kimura distances. The significance of each branch is indicated by a bootstrap value

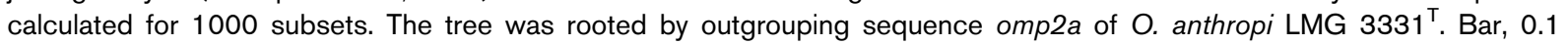
divergent residues per site. 
other Brucella species, was generated. AMOS PCR was negative using all primer combinations (data not shown). Finally, strain $\mathrm{BO}^{\mathrm{T}}$ was typed by using IS711 fingerprinting using the Southern blotting technique and by multilocus VNTR (variable-number tandem-repeat) analysis (MLVA) using eight mini- and eight micro-satellite VNTR markers as described recently for B. microti (Scholz et al., 2008a). Of the Brucella-specific insertion sequence IS711, four to five copies, displaying a unique banding pattern, were detected (Supplementary Fig. S3, in IJSEM Online). The MLVA typing pattern obtained was significantly different from those for previously analysed strains (Le Flèche et al., 2006; Al Dahouk et al., 2007). A new intermediate size allele was observed at locus Bruce42 (coded 2.5). No amplification product could be obtained at four loci, bruce07, bruce18, bruce 21 and bruce30 (Le Flèche et al., 2006), an exceptional behaviour not observed previously. All these loci are associated with an interspersed repeat element (containing one or two octameric tandem repeats) present in about 20 locations in B. melitensis $16 \mathrm{M}^{\mathrm{T}}$ strain as reported previously by Bricker et al. (2003). This suggests that these four loci are the result of recent spreading events of this presumably mobile element within the Brucella genus, after the occurrence of the last common ancestor to B. inopinata sp. nov. and to the other Brucellae. Alternatively, these four loci might have been lost or rearranged along the inopinata lineage as a result of their peculiar structure. MLVA cluster analysis using the categorical distance coefficient and the unweighted pairgroup method with arithmetic averages (UPGMA) was carried out as described previously (Scholz et al., 2008a). In these analyses, strain $\mathrm{BO}^{\mathrm{T}}$ clustered together with the B. microti, B. suis biovar 5 and B. neotomae strains and three representative marine mammal strains (Supplementary Fig. S4, in IJSEM Online) in a very loosely connected group with long branches. The inopinata branch is in proportion markedly shorter than the relatively very long branch observed by using MLST (De et al., 2008). This might be because of the inherent homoplasy at MLVA loci. Furthermore, relatively long evolutionary distances will be underestimated by MLVA as 16 markers were used in this MLVA assay, and the distance is the categorical coefficient; an MLVA distance between two strains cannot be more than 16. Another possibility is that VNTR markers do not evolve as fast in these presumably environmental species, in comparison with the highly pathogenic and host-adapted variants (the more classical Brucellae), which are under different stress conditions. However, as yet nothing is known about the natural reservoir or the host-range of this novel Brucella species.

From the phenotypic and molecular data it was obvious that strain $\mathrm{BO}^{\mathrm{T}}$ belonged to the genus Brucella but also differed from all recognized species and their biovars. We therefore conclude that $\mathrm{BO} 1^{\mathrm{T}}$ represents a novel species of the genus Brucella, for which the name Brucella inopinata sp. nov. is proposed.

\section{Description of Brucella inopinata sp. nov.}

Brucella inopinata (in.o.pi.na'ta. L. fem. adj. inopinata unexpected).

Aerobic, non-fermentative, non-motile, non-spore-forming, Gram-negative coccobacilli or short rods, $0.5-0.7 \mu \mathrm{m}$ in diameter and $0.6-1.2 \mu \mathrm{m}$ in length arranged individually or in irregular clusters. Non-fastidious, fast growth (visible within $6 \mathrm{~h}$ ) occurs on Brucella agar, trypticase soy agar (Becton Dickinson), sheep blood agar and standard nutrient agar at $25-42{ }^{\circ} \mathrm{C}$. Positive for growth on MacConkey agar (Becton Dickinson). Smooth, opaque colonies are formed within $18 \mathrm{~h}$, with a diameter of approximately 1-2 mm. Good growth does not require $\mathrm{CO}_{2}$, supplementary serum or blood. No haemolysis is observed. Growth occurs in the presence of thionin at concentrations of $1 / 25000,1 / 50000$ and $1 / 100000$, and with basic fuchsin at concentrations of 1/50 000 and 1/100 000 . Incomplete lysis occurs with bacteriophages $\mathrm{Tb}, \mathrm{F} 1$ and F25 at $10^{4} \times \mathrm{RTD}$, but not at other dilutions. Agglutinates with monospecific anti-M serum up to a dilution of $1: 40$. Oxidase- and catalase-positive. Fast urease reaction ( $<5 \mathrm{~min})$. Growth occurs in nutrient broth with or without $6 \% \mathrm{NaCl}$. Nitrate and nitrite are reduced (with gas formation from nitrate). Production of $\mathrm{H}_{2} \mathrm{~S}$ and Voges-Proskauer reaction are positive. Negative for hydrolysis of aesculin, gelatin liquefaction, production of indole, citrate utilization, growth on cetrimide and Salmonella-Shigella (SS) agar. Acid production is observed in King's oxidation-fermentation base from D-glucose and D-xylose, whereas no acid production is observed in King's oxidation-fermentation base from mannitol, lactose, sucrose and maltose. Positive (API ZYM) for acid phosphatase, alkaline phosphatase, trypsin, leucine arylamidase and naphthol-AS-BI-phosphohydrolase. Negative (API ZYM) for esterase, esterase lipase, lipase, valine arylamidase, cystine arylamidase, $\alpha$-chymotrypsin, $\alpha$ - and $\beta$-galactosidase, $\beta$-glucuronidase, $\alpha$ - and $\beta$-glucosidase, $N$-acetyl- $\beta$-glucosaminidase, $\alpha$-mannosidase and $\alpha$-fucosidase. Positive (API 20NE) for D-glucose, maltose, L-arabinose, D-mannose, $\mathrm{N}$-acetylglucosamine and adipic acid. Negative for D-mannitol, citric acid, gluconate, capric acid, malic acid and phenylacetic acid. In API 20E, positive for fermentation of L-arabinose. Additional differential physiological reactions (MICRONAUT) of strain $\mathrm{BO}^{\mathrm{T}}$ in comparison with other Brucella species and biovars and O. anthropi LMG $3331^{\mathrm{T}}$ are given in Table 1. Susceptible to the following antimicrobial agents: doxycycline $(0.12 \mu \mathrm{g}$ $\left.\mathrm{ml}^{-1}\right)$, tetracycline $\left(0.25 \mu \mathrm{g} \mathrm{m} l^{-1}\right)$, streptomycin $(2 \mu \mathrm{g}$ $\left.\mathrm{ml}^{-1}\right)$, gentamicin $\left(1 \mu \mathrm{g} \mathrm{ml}{ }^{-1}\right)$ and trimethoprim-sulfamethoxazole $\left(<0.5\right.$ and $\left.9.5 \mu \mathrm{g} \mathrm{ml}^{-1}\right)$. Major whole-cell cellular fatty acids (5-46\%) are $\mathrm{C}_{19: 0}$ cyclo 11-12, $\mathrm{C}_{18: 1} \omega 7 \mathrm{c}, \mathrm{C}_{18: 0}$ and $\mathrm{C}_{16: 0}$, and smaller amounts (1-4\%) of $\mathrm{Br}-\mathrm{C}_{19: 1}$. Quinone system is composed of the major compound ubiquinone Q-10 and minor amounts of Q-11. The polar lipid profile contains the major compounds phosphatidylethanolamine, phosphatidylglycerol, diphosphatidylglycerol, phosphatidylcholine and one unknown 
aminolipid, moderate amounts of phosphatidylmonomethylethanolamine and minor to trace amounts of an unknown aminophospholipid, an unknown phospholipid and two unknown polar lipids. The polyamine pattern consists of the major compounds spermidine and putrescine and small amounts of 1.3-diaminopropane, symhomospermidine and spermine.

The type strain, $\mathrm{BO}^{\mathrm{T}}\left(=\mathrm{BCCN} 09-01^{\mathrm{T}}=\mathrm{CPAM} 6436^{\mathrm{T}}\right)$, was isolated in 2005 from a breast implant infection of a 71-year-old female patient in the USA.

\section{Acknowledgements}

We are grateful to Csilla Lodri, Stefan Schatz, Robert Schneider, and Angelika Draeger for excellent technical assistance. The development of genotyping methods for the precise strain identification of dangerous pathogens as part of microbial forensics is supported by the French DGA (Délégation Générale pour l'Armement). MRIS and BIM are members of the European Biodefense Laboratory Network (EBLN) supported by the European Defence Agency (EDA). We thank Philippe Le Flèche for the MLVA typing and Mark S Koylass for MLST analysis of strain $\mathrm{BO}^{\mathrm{T}}$.

\section{References}

Al Dahouk, S., Fleche, P. L., Noeckler, K., Jacques, I., Grayon, M., Scholz, H. C., Tomaso, H., Vergnaud, G. \& Neubauer, H. (2007). Evaluation of Brucella MLVA typing for human brucellosis. J Microbiol Methods 69, 137-145.

Altenburger, P., Kämpfer, P., Makristathis, A., Lubitz, W. \& Busse, H.-J. (1996). Classification of bacteria isolated from a medieval wall painting. J Biotechnol 47, 39-52.

Bricker, B. J. \& Halling, S. M. (1994). Differentiation of Brucella abortus bv. 1, 2, and 4, Brucella melitensis, Brucella ovis and Brucella suis bv. 1 by PCR. J Clin Microbiol 32, 2660-2666.

Bricker, B. J., Ewalt, D. R. \& Halling, S. M. (2003). Brucella 'HOOFPrints': strain typing by multi-locus analysis of variable number tandem repeats (VNTRs). BMC Microbiol 11, 3-15.

Buddle, M. B. (1956). Studies on Brucella ovis (n. sp.), a cause of genital disease of sheep in New Zealand and Australia. J Hyg (Lond) 54, 351-364.

Carmichael, L. E. \& Bruner, D. W. (1968). Characteristics of a newlyrecognized species of Brucella responsible for infectious canine abortions. Cornell Vet 48, 579-592.

Crasta, O. R., Folkerts, O., Fei, Z., Mane, S. P., Evans, C., MartinoCatt, S., Bricker, B., Yu, G., Du, L. \& Sobral, B. W. (2008). Genome sequence of Brucella abortus vaccine strain S19 compared to virulent strains yields candidate virulence genes. PLoS One 3, e2193.

De, B. K., Stauffer, L., Koylass, M. S., Sharp, S. E., Gee, J. E., Helsel, L. O., Steigerwalt, A. G., Vega, R., Clark, T. A. \& other authors (2008). Novel Brucella strain (BO1) associated with a prosthetic breast implant infection. J Clin Microbiol 46, 43-49.

DelVecchio, V. G., Kapatral, V., Redkar, R. J., Patra, G., Mujer, C., Los, T., Ivanova, N., Anderson, I., Bhattacharyya, A. \& other authors (2002). The genome sequence of the facultative intracellular pathogen Brucella melitensis. Proc Natl Acad Sci U S A 99, 443-448.

Foster, G., Osterman, B., Godfroid, J., Jacques, I. \& Cloeckaert, A. (2007). Brucella ceti sp. nov. and Brucella pinnipedialis sp. nov. for Brucella strains with cetaceans and seals as their preferred hosts. Int $J$ Syst Evol Microbiol 57, 2688-2693.
Garcia-Yoldi, D., Marin, C. M., de Miguel, M. J., Munoz, P. M., Vizmanos, J. L. \& Lopez-Goni, I. (2006). Multiplex PCR assay for the identification and differentiation of all Brucella species and the vaccine strains Brucella abortus S19 and RB51 and Brucella melitensis Rev1. Clin Chem 52, 779-781.

Gee, J. E., De, B. K., Levett, P. N., Whitney, A. M., Novak, R. T. \& Popovic, T. (2004). Use of $16 \mathrm{~S}$ rRNA gene sequencing for rapid confirmatory identification of Brucella isolates. J Clin Microbiol 42, 3649-3654.

Halling, S. M., Peterson-Burch, B. D., Bricker, B. J., Zuerner, R. L., Qing, Z., Li, L. L., Kapur, V., Alt, D. P. \& Olsen, S. C. (2005). Completion of the genome sequence of Brucella abortus and comparison to the highly similar genomes of Brucella melitensis and Brucella suis. J Bacteriol 187, 2715-2726.

Hubalek, Z., Scholz, H. C., Sedlaceck, I., Melzer, F., Sanogo, Y \& Nesvadbova, J. (2007). Brucellosis of the Common Vole (Microtus arvalis). Vector Borne Zoonotic Dis 7, 679-687.

Huddleson, I. F. (1929). The differentiation of the species of the genus Brucella. Michigan State College Agricultural Experimental Station Technical Bulletin 100, 1-16.

Jevitt, L. A., Weigel, L. M., De, B., Popovic, T. \& Patel, J. B. (2005). Abstr. C-357. Abstr. 105th Gen. Meet. Am. Soc. Microbiol. Washington, DC: American Society for Microbiology.

Le Flèche, P., Jacques, I., Grayon, M., Al Dahouk, S., Bouchon, P., Denoeud, F., Nockler, K., Neubauer, H., Guilloteau, L. A. \& other authors (2006). Evaluation and selection of tandem repeat loci for a Brucella MLVA typing assay. BMC Microbiol 9, 6-9.

Meyer, K. F. \& Shaw, E. B. (1920). A comparison of the morphologic, cultural and biochemical characteristics of B. abortus and B. melitensis from cattle. Studies on the genus Brucella nov. gen. J Infect Dis 27, 173-184.

Osterman, B. \& Moriyón, I. (2006). International Committee on Systematics of Prokaryotes; Subcommittee on the Taxonomy of Brucella: minutes of the meeting, 17 September 2003, Pamplona, Spain. Int J Syst Evol Microbiol 56, 1173-1175.

Paulsen, I. T., Seshadri, R., Nelson, K. E., Eisen, J. A., Heidelberg, J. F., Read, T. D., Dodson, R. J., Umayam, L., Brinkac, L. M. \& other authors (2002). The Brucella suis genome reveals fundamental similarities between animal and plant pathogens and symbionts. Proc Natl Acad Sci U S A 99, 13148-13153.

Scholz, H. C., Hubalek, Z., Sedlácek, I., Vergnaud, G., Tomaso, H., Al Dahouk, S., Melzer, F., Kämpfer, P., Neubauer, H. \& other authors (2008a). Brucella microti sp. nov., isolated from the common vole Microtus arvalis. Int J Syst Evol Microbiol 58, 375-382.

Scholz, H. C., Al Dahouk, S., Tomaso, H., Neubauer, H., Witte, A., Schloter, M., Kämpfer, P., Falsen, E., Pfeffer, M. \& Engel, M. (2008b). Genetic diversity and phylogenetic relationships of bacteria belonging to the Ochrobactrum-Brucella group by recA and 16S rRNA gene-based comparative sequence analysis. Syst Appl Microbiol 31, 116.

Scholz, H. C., Hubalek, Z., Nesvadbova, J., Tomaso, H., Vergnaud, G., Le Flèche, P., Whatmore, A. M., Al Dahouk, S., Krüger, M. \& other authors (2008c). Isolation of Brucella microti from soil. Emerg Infect Dis 14, 1316-1317.

Scholz, H. C., Hofer, E., Vergnaud, G., Le Flèche, P., Whatmore, A. M., Al Dahouk, S., Pfeffer, M., Krüger, M., Cloeckaert, A. \& Tomaso, H. (2009). Isolation of Brucella microti from mandibular lymph nodes of red foxes, Vulpes vulpes, in Lower Austria. Vector Borne Zoonotic Dis 9 , 153-156.

Stoenner, H. G. \& Lackman, D. B. (1957). A new species of Brucella isolated from the desert wood rat, Neotoma lepida Thomas. Am J Vet Res 18, 947-951. 
Thompson, J. D., Higgins, D. G. \& Gibson, T. J. (1994). CLUSTAL W: improving the sensitivity of progressive multiple sequence alignment through sequence weighting, position-specific gap penalties and weight matrix choice. Nucleic Acids Res 22, 46734680.

Tindall, B. J. (1990a). A comparative study of the lipid composition of Halobacterium saccharovorum from various sources. Syst Appl Microbiol 13, 128-130.

Tindall, B. J. (1990b). Lipid composition of Halobacterium lacusprofundi. FEMS Microbiol Lett 66, 199-202.
Verger, J.-M., Grimont, F., Grimont, P. A. D. \& Grayon, M. (1985) Brucella, a monospecific genus as shown by deoxyribonucleic acid hybridization. Int J Syst Bacteriol 35, 292-295.

Wayne, L. G., Brenner, D. J., Colwell, R. R., Grimont, P. A. D., Kandler, O., Krichevsky, M. I., Moore, L. H., Moore, W. E. C., Murray, R. G. E. \& other authors (1987). Report of the ad hoc committee on reconciliation of approaches to bacterial systematics. Int J Syst Bacteriol 37, 463-464.

Whatmore, A. M., Perrett, L. L. \& Macmillan, A. P. (2007). Characterisation of the genetic diversity of Brucella by multilocus sequencing. BMC Microbiol 7, 34. 